\title{
Endogenous Activation of Group-I Metabotropic Glutamate Receptors Is Required for Differentiation and Survival of Cerebellar Purkinje Cells
}

\author{
M. V. Catania, ${ }^{1}$ M. Bellomo, ${ }^{2}$ V. Di Giorgi-Gerevini, ${ }^{3}$ G. Seminara, ${ }^{1,4}$ R. Giuffrida, ${ }^{5}$ R. Romeo, ${ }^{6}$ A. De Blasi, ${ }^{7,8}$ \\ and F. Nicoletti ${ }^{3,8}$ \\ $1 /$ nstitute for Bioimaging and Pathophysiology of the Central Nervous System (IBFSNC), National Research Council \\ (IBFSNC-CNR), 95123 Catania, Italy, 2Institute of Physiology, University of Messina, 98100 Messina, Italy, ${ }^{3}$ Department of \\ Human Physiology and Pharmacology, University of Roma La Sapienza, Rome, Italy, Departments of ${ }^{4}$ Chemical Sciences \\ and ${ }^{5}$ Physiological Sciences and 6/nstitute of Anatomy, University of Catania, 95100 Catania, Italy, ${ }^{7}$ Department of \\ Molecular Pharmacology and Pathology, "Mario Negri Sud" Institute, 66030 S. Maria Imbaro (Chieti), and 8I. N. M. \\ Neuromed, 86077 Pozzilli, Italy
}

We have applied subtype-selective antagonists of metabotropic glutamate (mGlu) receptors mGlu1 or mGlu5 [7-(hydroxyimino) cyclopropa[b]chromen-1a-carboxylate ethyl ester (CPCCOEt) or 2-methyl-6-(phenylethynyl)pyridine (MPEP)] to mixed rat cerebellar cultures containing both Purkinje and granule cells. The action of these two drugs on neuronal survival was cell specific. Although CPCCOEt $(1,10,30 \mu \mathrm{M})$ reduced the survival of Purkinje cells, MPEP (3 or $30 \mu \mathrm{M}$ ) selectively reduced the survival of granule cells. Both effects required an early exposure of cultures to antagonists [from 3 to $6 \mathrm{~d}$ in vitro (DIV) for CPCCOEt, and from 3 to 6 or 6 to 9 DIV for MPEP]. Addition of MPEP from 6 to 9,9 to 13 , or 13 to 17 DIV also induced profound morphological changes in the dendritic tree and dendritic spines of Purkinje cells, suggesting that endogenous activation of mGlu5 receptors is required for the age-dependent refinement of Purkinje cell phenotype. In in vivo studies, an early blockade of mGlu1 receptors induced in rats by local injections of LY367385 $(20 \mathrm{nmol} / 2 \mu \mathrm{l})$, local injections of mGlu1 antisense oligonucleotides $(12 \mathrm{nmol} / 2 \mu \mathrm{l})$, or systemic administration of CPCCOEt ( $5 \mathrm{mg} / \mathrm{kg}$, s.c.) from postnatal day (P) 3 to $\mathrm{P} 9$ reduced the number and dramatically altered the morphology of cerebellar Purkinje cells. In contrast, mGlu5 receptor blockade induced by local injections of antisense oligonucleotides reduced the number of granule cells but also produced substantial morphological changes in the dendritic tree of Purkinje cells. These results provide the first evidence that the development of cerebellar neurons is under the control of mGlu1 and mGlu5 receptors, i.e., the two mGlu receptor subtypes coupled to polyphosphoinositide hydrolysis.

Key words: metabotropic glutamate receptors; Purkinje cells; granule cells; cerebellum; development; dendrites
Activation of glutamate receptors has been implicated in the regulation of differentiation and survival of developing CNS neurons. Most of the studies have focused on the role of NMDA receptors in the induction of neuronal phenotypes, promotion of neuronal survival, and synaptic remodeling during development (Balázs et al., 1988; Moran and Patel, 1989; Rabacchi et al., 1992; Burgoyne et al., 1993; Yuzaki et al., 1996; Marini et al., 1998). However, metabotropic glutamate (mGlu) receptors have also been implicated in the regulation of developmental plasticity since the early times of their characterization (Nicoletti et al., 1986; Dudek and Bear, 1989). mGlu receptors form a family of eight subtypes (named mGlu1 to mGlu8), of which mGlu1 and mGlu5 receptors, which form the first subgroup of subtypes, are coupled to polyphosphoinositide (PI) hydrolysis (Nakanishi, 1982; Pin and Duvoisin, 1995). Glutamate-stimulated PI hydrolysis in brain slices shows a developmental peak in the early

\footnotetext{
Received May 4, 2001; revised July 11, 2001; accepted July 17, 2001.

This work was supported by Telethon Grant 1238. We thank M. Cascone for excellent technical assistance.

Correspondence should be addressed to Dr. Maria Vincenza Catania, Bioimaging and Pathophysiology of the Central Nervous System-National Research Council (IBFSNC-CNR), VI Regina Marherita 6, 95123 Catania, Italy. E-mail: mcatania@area.ct.cnr.it.

Copyright (C) 2001 Society for Neuroscience $\quad 0270-6474 / 01 / 217664-10 \$ 15.00 / 0$
}

postnatal life and then progressively decreases with age (Nicoletti et al., 1986; Schoepp and Johnson, 1989). This is paralleled by an early peak in the expression of mGlu5 receptors in most of the brain regions, including the cerebellum (Catania et al., 1994; Minakami et al., 1995; Romano et al., 1996; Casabona et al., 1997). In the kitten visual cortex, the activity of mGlu receptors coupled to PI hydrolysis is greater between 3 and 5 weeks of postnatal life, a time that corresponds to the critical period of synaptic modification in response to monocular deprivation (Dudek and Bear, 1989). A developmental pattern of expression of group-I mGlu receptors is also shown in cultured cerebellar granule cells, in which glutamate-stimulated PI hydrolysis peaks after $4 \mathrm{~d}$ in vitro (DIV) and declines at later stages of maturation (Aronica et al., 1993). Interestingly, an early activation of mGlu5 receptors supports the survival of cultured granule cells (Copani et al., 1998), raising the possibility that the age-dependent reduction in the expression of mGlu5 receptors contributes to the elimination of supranumerary granule cells in the intact cerebellum. Pharmacological activation of mGlu receptors combined with NGF application increases Purkinje cell survival in culture (Mount et al., 1993), but which receptor subtype is involved and whether this effect is physiologically relevant are unknown. Purkinje cells are highly enriched in mGlu1 receptors (Aramori and Nakanishi, 1992; Görcs et al., 1993; Catania et al., 1994), but 
CONTROL

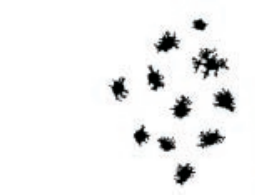

6 DIV
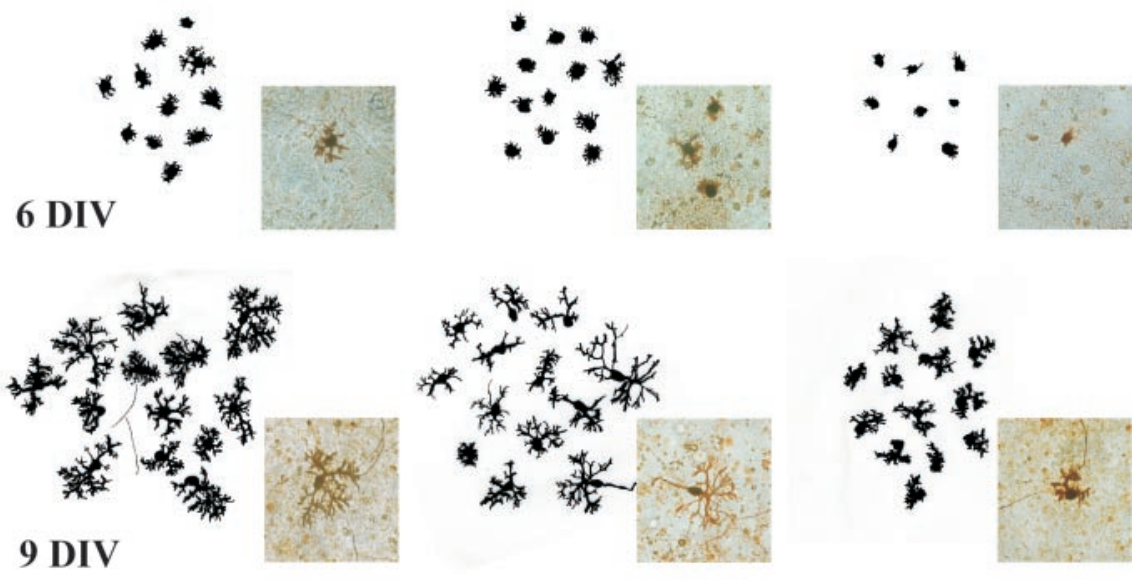

13 DIV
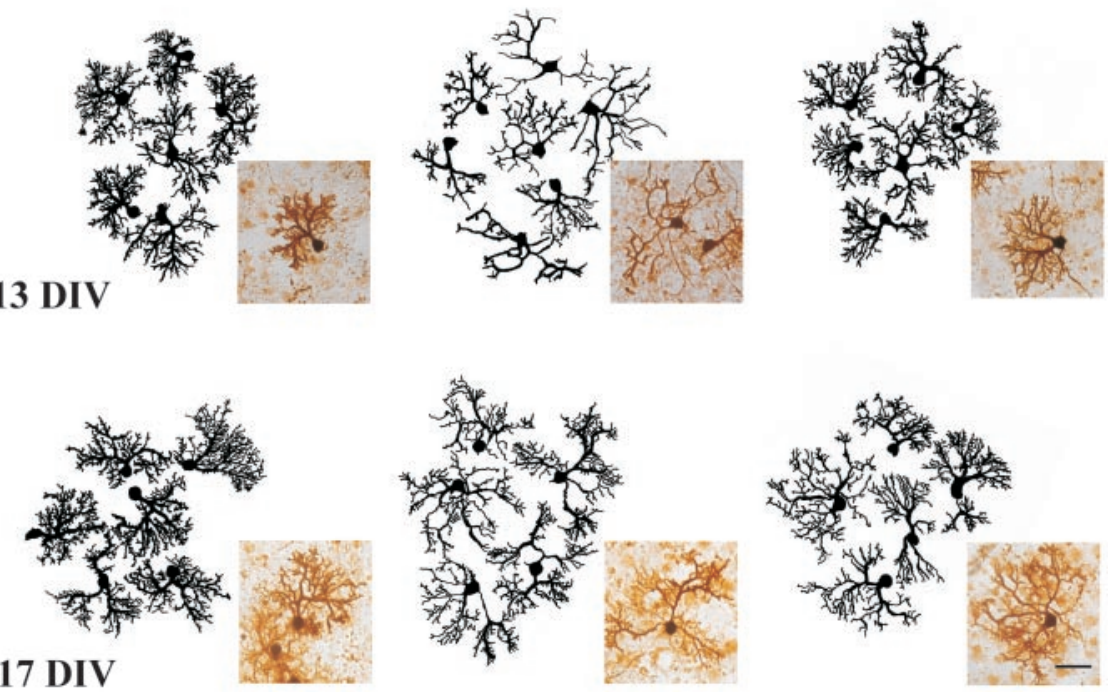

Figure 1. Morphological differentiation of cultured Purkinje cells in the absence (CONTROL) or presence of MPEP or CPCCOEt. Here, the effects of 30 $\mu \mathrm{M}$ MPEP and $30 \mu \mathrm{M}$ CPCCOEt are illustrated. Similar effects are seen with 1 or $10 \mu \mathrm{M} \mathrm{CPCCOEt} \mathrm{and} 3$ $\mu \mathrm{M}$ MPEP (data not shown). Drugs were administered between 3 and 6 ( 6 DIV), 6 and 9 ( 9 DIV), 9 and 13 (13 DIV), or 13 and 17 (17 DIV) DIV, and Purkinje cells were visualized at the indicated DIV, by immunostaining with an anti-calbindin antibody. Representative drawings of several Purkinje cells (left top side) were traced from microphotographs (right bottom side of each panel). Similar data were obtained in three experiments from different culture preparations $(n=$ 3-4). Scale bar, $50 \mu \mathrm{m}$.
mGlu1 knock-out mice show no apparent changes in the number and only minor changes in the morphology of Purkinje cells (Aiba et al., 1994). Similarly, the gross anatomy of the cerebellum is unchanged in mGlu5 knock-out mice (Lu et al., 1997). Because compensatory changes might have occurred in knock-out mice, we decided to use novel subtype-selective mGlu1 or mGlu5 receptor antagonists or antisense oligonucleotides to examine how endogenous activation of these receptors affects the development of Purkinje cells.

\section{MATERIALS AND METHODS}

\section{Materials}

7-(Hydroxy-imino) cyclopropa[b]chromen-1a-carboxylate ethyl ester (CPCCOEt), 2-methyl-6-(phenylethynyl)pyridine (MPEP), and (E)-2methyl-6-styryl-pyridine (SIB-1893) were purchased from Tocris Cookson (Bristol, UK). 2-Methyl-4-carboxyphenyglycine (LY367385) and $\alpha$-thioxanth-9-ylmethyl-4-carboxyphenylglycine (LY367366) were kind gifts from Dr. Ann Kingston (Eli Lilly, UK).

\section{Mixed cerebellar cultures}

Mixed cerebellar cultures were prepared from rats at postnatal day $(\mathrm{P}) 1$, as described previously (Furuya et al., 1998). Cells were plated at a final density of $5 \times 10^{6}$ cells/ml in DMEM/F12 containing putrescine (100 $\mu \mathrm{M})$, sodium selenite $(30 \mathrm{nM})$, progesterone $(20 \mathrm{nM})$, bovine insulin $(10$ $\mu \mathrm{g} / \mathrm{ml})$, transferrin $(100 \mu \mathrm{g} / \mathrm{ml})$, tri-iodothyronine (T3) $(0.5 \mathrm{ng} / \mathrm{ml})$, bovine serum albumin $(0.1 \mathrm{mg} / \mathrm{ml})$, glutamine $(3.9 \mathrm{mM})$, gentamicin $(10$ $\mu \mathrm{g} / \mathrm{ml})$, and $1 \%$ FCS. The medium was partially replaced at 9 DIV with fresh serum-free DMEM/F12 containing the supplements and cytosine arabino- $\beta$-furanoside $(4 \mu \mathrm{M})$. Cell cultures were treated daily with MPEP and CPCCOEt dissolved in serum-free DMEM/F12. Three different types of treatment were performed: (1) in a first set of experiments, cultures were treated continuously with drugs from 4 to $13 \mathrm{DIV}$; (2) in a second set of experiments, cultures were treated only for 3 or $4 \mathrm{~d}$ at critical stages of Purkinje cell development. In particular, dishes were divided into four groups and treated from 3 to 5 DIV (and analyzed at 6 DIV); from 6 to 8 DIV (and analyzed at 9 DIV); from 9 to 12 DIV (and analyzed at 13 DIV); or from 13 to 16 DIV (and analyzed at 17 DIV). (3) In a third set of experiments, cultures were treated from 6 to 9 DIV with MPEP or CPCCOEt, extensively washed, and then analyzed at 14 DIV. Granule cell counting and morphological analysis of Purkinje cells were performed on the same dishes.

\section{Animal treatment}

Sprague Dawley newborn rats at $\mathrm{P} 3$ were injected through the scalp in the posterior region of the cerebellum $(2-3 \mathrm{~mm}$ posterior to the lambda point) under conditions of deep hypothermia. The drugs LY367385 or LY367366 (both at doses of $20 \mathrm{nmol} / 2 \mu \mathrm{l}$ ) were injected once every $2 \mathrm{~d}$ until P9. Animals were killed at P9-10. In different animals we injected methylene blue to validate the site of injection. The region of injection was invariably located in the vermis in a region comprising the central lobe (lobules VI, VII, and VIII), and the dye diffused anteriorly to anterodorsal lobe (lobules IV and V) and posteriorly to lobule IX as indicated in Altman and Bayer (1996). "End-capped" antisense oligonucleotides (Oligo Therapeutics Inc.) directed against mGlu1 or mGlu5 mRNA were injected at doses of $12 \mathrm{nmol} / 2 \mu \mathrm{l}$ only at P3 and P5 (animals were killed at P9). The antisense sequences were as follows: T(s)C(s)AGGCAGGCATCGGTTC(s)A(s)G, corresponding to the position 785-805 of mGlu1 sequence (GenBank accession number M61099) (Houamed et 

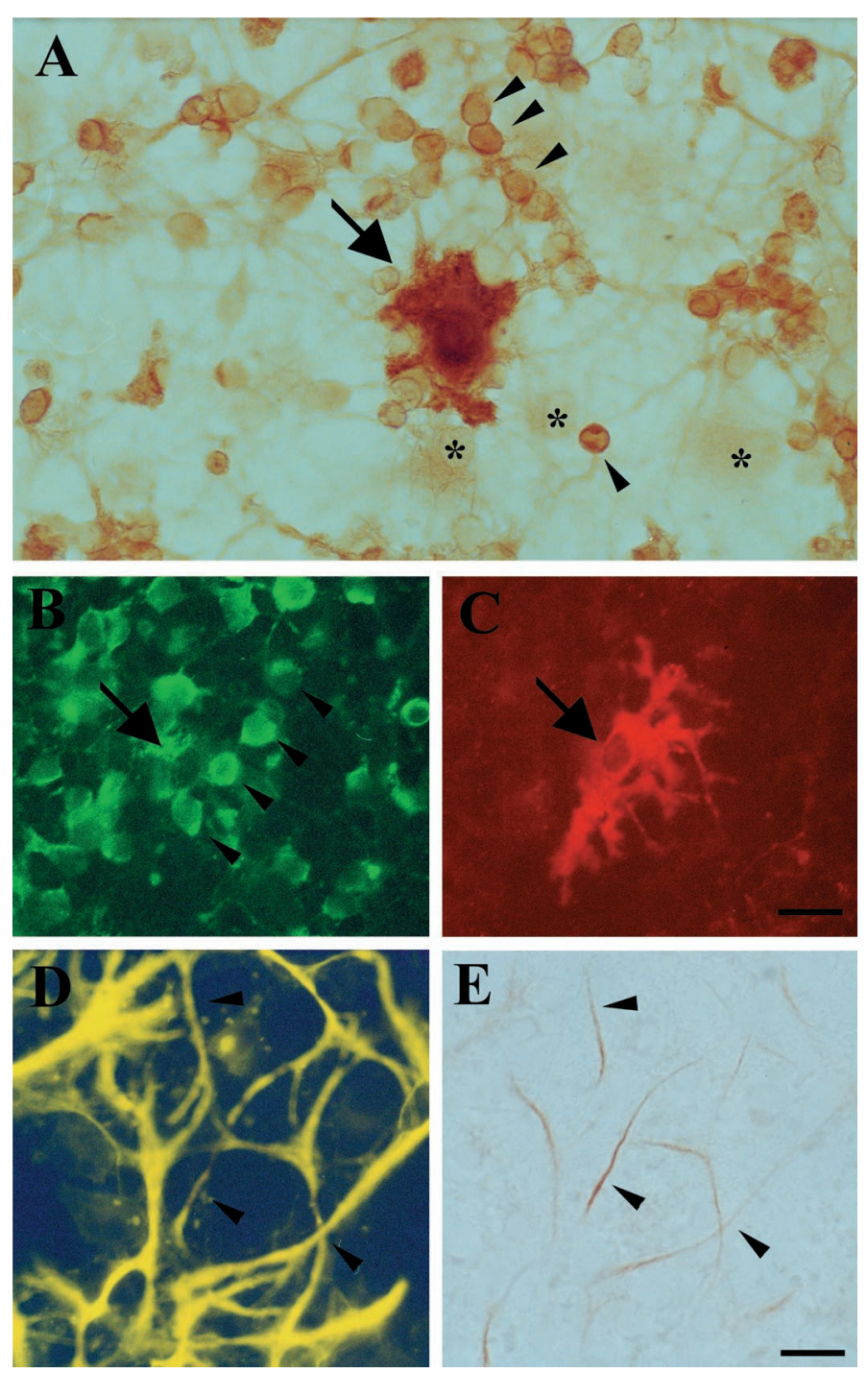

Figure 2. Expression of mGlu1a and mGlu5 receptors in Purkinje, granule, and glial cells in cerebellar cultures. $A$ shows the expression of the mGlu1a receptor in granule (arrowheads) and Purkinje cells (arrow) in a representative culture at 6 DIV. The receptor is expressed in both cell types at any developmental stages since at least 3 DIV. Note the absence of staining in glial cells (asterisks). A double immunostaining for mGlu5 receptors (green) and calbindin (red) is shown in $B$ and $C$, respectively. Note that mGlu5 receptors are expressed in granule cells (arrowheads) but not in Purkinje cells (arrow). A double immunostaining for GFAP (yellow) and mGlu5 antibodies (DAB staining) is shown in $D$ and $E$. Note the presence of mGlu5 receptors in glial processes. Scale bars: $A, 40 \mu \mathrm{m}$; $B-E, 50 \mu \mathrm{m}$.

al., 1991), and G(s)G(s)ATCAACAGAAGGACCA(s)T(s)T, corresponding to position 267-286 of mGlu5 sequence (GenBank accession number D10891) (Abe et al., 1992). A scrambled mGlu5 oligonucleotide having the sequence G(s)G(s)ACTAAACAGGAGACAT(s)C(s)T was used as a control. CPCCOEt $(5 \mathrm{mg} / \mathrm{kg}$ ) was daily injected subcutaneously from $\mathrm{P} 3$ to $\mathrm{P} 9$.

\section{Western blotting}

Western blot analysis of mGlu5 receptors in rat hemicerebella was performed as described previously (Copani et al., 1998).

\section{Immunocytochemistry}

Cultures. Cells were generally fixed with $4 \%$ paraformaldehyde $/ 4 \%$ sucrose in Tris-buffered saline (TBS; $100 \mathrm{~mm}$ Tris, $0.9 \% \mathrm{NaCl}$ ) for $15 \mathrm{~min}$. For mGlu1a staining, fixation with ice-cold methanol was preferred
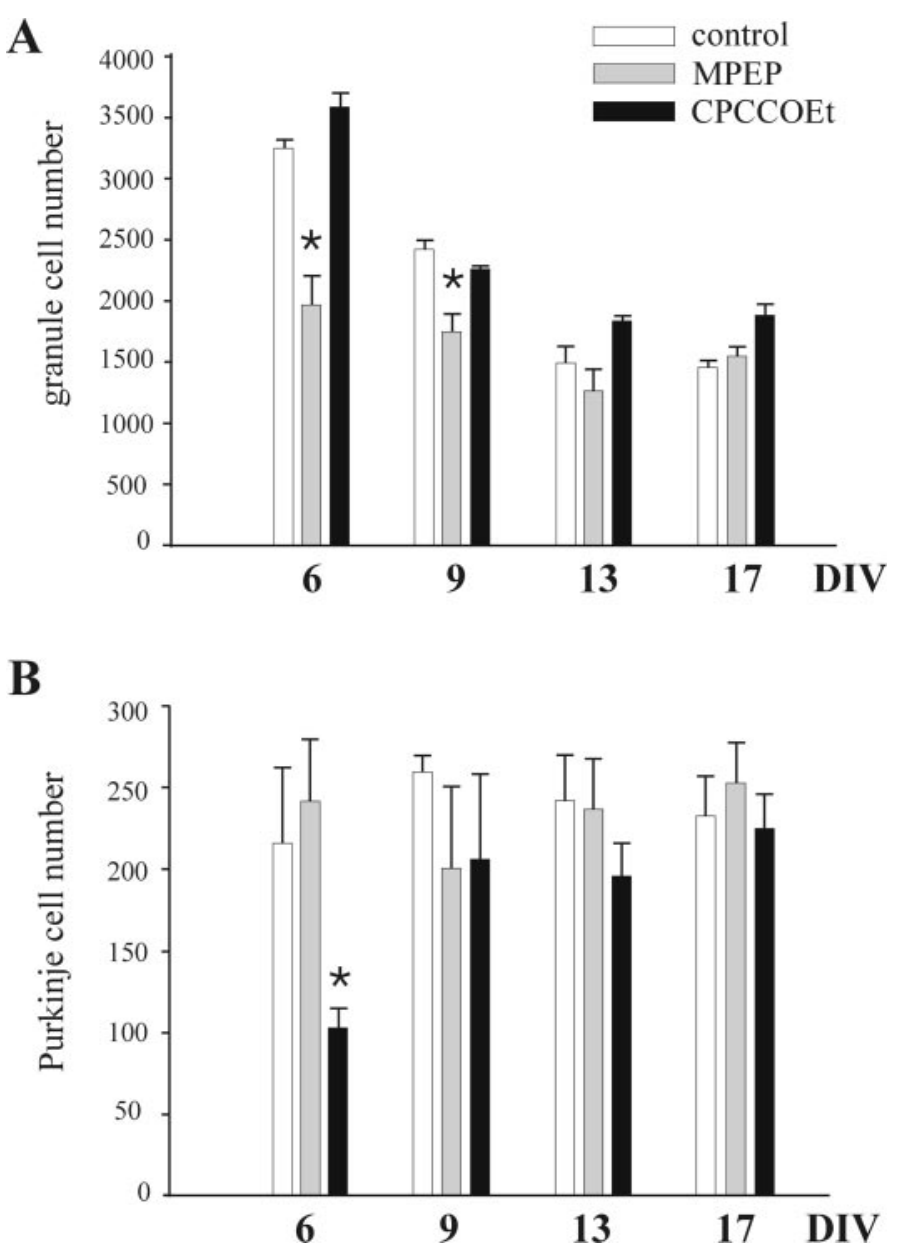

Figure 3. Effects of MPEP or CPCCOEt treatment on granule $(A)$ and Purkinje $(B)$ cell number in cerebellar cultures. Drugs were applied to the cultures as described in Figure 1. Cells were counted in four random fields per dish. Values are means \pm SEM of four individual culture dishes. ${ }^{*} p<$ 0.05 (one-way ANOVA + Fisher's PLSD) versus control values. Similar data were obtained in three experiments on different culture preparations.

because it resulted in a more clearly defined signal than with paraformaldehyde. Permeabilization was performed in TBS with $0.1 \%$ Triton X-100 for 5 min. After blocking with $4 \%$ normal goat serum (NGS) for 30 min, incubation with primary antibodies was performed overnight at $4^{\circ} \mathrm{C}$. A mouse monoclonal antibody against calbindin (1:1000; Swant, Bellinzona, Switzerland), rabbit polyclonal antibodies anti-glutamate decarboxylase (GAD)-67 (1:1000; Chemicon International, Temecula, CA), and rabbit polyclonal antibodies against mGlu1a (1:100; Chemicon International) and five (1:100; Upstate Biotechnology, Lake Placid, NY) receptors were used. The following antigenic peptides (one-letter code), CPNVTYASVILRDYKQSSSTL (corresponding to the C terminus of the mGlu1a receptors) and KSSPKDTLIIRDYTNSSSSL (corresponding to the $\mathrm{C}$ terminus of mGlu5a/b receptors), were used to test the specificity of immunolabeling. Both peptides were kindly provided by $\mathrm{Dr}$ R. Kuhn (Novartis Pharma, Basle, Switzerland). After three washes in TBS, biotin-conjugated goat anti-rabbit or anti-mouse secondary antibodies (1:200, Vector Laboratories, Burlingame, CA) were added for 1.5 hr. Immunostaining was revealed by the avidin-biotin-peroxidase method. In the mGlu5/calbindin double-labeling experiment, a dichlorotriazinyl amino fluorescein (DTAF)-conjugated goat anti-rabbit IgG (1:200; Jackson ImmunoResearch, West Grove, PA) and a Cy3conjugated goat anti-mouse IgG (1:200; Jackson ImmunoResearch) were used. In the mGlu5/GFAP double-labeling experiment, staining for mGlu5 was first developed using the DAB method; cultures were then fixed in paraformaldehyde for 10 min, blocked with $4 \%$ goat serum, and incubated again overnight with a rabbit anti-cow GFAP antibody (1:1000; Dako) that was revealed with a secondary DTAF-conjugated goat anti- 
Table 1. Effect of MPEP or CPCCOEt treatment on Purkinje cell dendrites in culture

\begin{tabular}{|c|c|c|c|c|c|c|c|c|c|}
\hline & \multicolumn{3}{|c|}{ Total length of the dendritic tree $(\mu \mathrm{m})$} & \multicolumn{3}{|c|}{ Number of dendritic branches } & \multicolumn{3}{|c|}{ Diameter of primary dendrites } \\
\hline & $9 \mathrm{DIV}$ & 13 DIV & 17 DIV & $9 \mathrm{DIV}$ & 13 DIV & 17 DIV & 9 DIV & 13 DIV & 17 DIV \\
\hline Control & $\begin{array}{l}1173 \pm 86 \\
(n=12)\end{array}$ & $\begin{array}{l}2757 \pm 298 \\
(n=19)\end{array}$ & $\begin{array}{l}3707 \pm 453 \\
(n=7)\end{array}$ & $\begin{array}{l}59 \pm 3 \\
(n=12)\end{array}$ & $\begin{array}{l}117 \pm 12 \\
(n=10)\end{array}$ & $\begin{array}{l}104 \pm 7 \\
(n=7)\end{array}$ & $\begin{array}{l}7.41 \pm 0.2 \\
(n=79)\end{array}$ & $\begin{array}{l}5.35 \pm 0.2 \\
(n=31)\end{array}$ & $\begin{array}{l}6.24 \pm 0.2 \\
(n=26)\end{array}$ \\
\hline MPEP & $\begin{array}{l}831 \pm 44^{*} \\
(n=10)\end{array}$ & $\begin{array}{l}1470 \pm 133^{*} \\
(n=11)\end{array}$ & $\begin{array}{l}4390 \pm 499 \\
(n=7)\end{array}$ & $\begin{array}{l}40 \pm 2^{*} \\
(n=10)\end{array}$ & $\begin{array}{c}44 \pm 5^{*} \\
(n=11)\end{array}$ & $\begin{array}{l}118 \pm 10 \\
(n=7)\end{array}$ & $\begin{array}{l}5.96 \pm 0.2^{*} \\
(n=51)\end{array}$ & $\begin{array}{l}4.02 \pm 0.1^{*} \\
(n=50)\end{array}$ & $\begin{array}{l}5.06 \pm 0.2^{*} \\
(n=24)\end{array}$ \\
\hline CPCCOEt & $\begin{array}{l}781 \pm 59^{*} \\
(n=13)\end{array}$ & $\begin{array}{l}2823 \pm 361 \\
(n=13)\end{array}$ & $\begin{array}{l}4408 \pm 238 \\
(n=7)\end{array}$ & $\begin{array}{l}33 \pm 1^{*} \\
(n=13)\end{array}$ & $\begin{array}{c}97 \pm 6 \\
(n=13)\end{array}$ & $\begin{array}{c}96 \pm 4 \\
(n=7)\end{array}$ & $\begin{array}{l}7.16 \pm 0.2 \\
(n=68)\end{array}$ & $\begin{array}{l}5.61 \pm 0.2 \\
(n=37)\end{array}$ & $\begin{array}{l}5.654 \pm 0.1 \\
(n=37)\end{array}$ \\
\hline
\end{tabular}

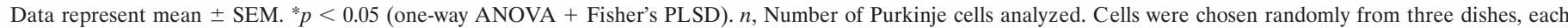
from a different experiment.

rabbit IgG (1:200; Jackson ImmunoResearch). Granule cells were visualized by nuclear staining with the fluorescent chromatin dye Hoechst $33258(0.8 \mu \mathrm{g} / \mathrm{ml})$ for $30 \mathrm{~min}$ in $10 \mathrm{~mm}$ PBS at $37^{\circ} \mathrm{C}$. Chromatin staining was always performed after $\mathrm{DAB} /$ anti-calbindin immunostaining for the simultaneous visualization of Purkinje and granule cells.

Intact cerebellum. Brains were removed and fixed in $4 \%$ paraformaldehyde/PBS for $2 \mathrm{~d}$ at $4^{\circ} \mathrm{C}$ and then cryoprotected in $30 \%$ sucrose for 3-7 d. Sagittal sections ( $20 \mu \mathrm{m}$ thick) were cut at the cryostate and serially attached to gelatin-coated slides. Slices were permeabilized for $30 \mathrm{~min}$ in TBS containing $0.2 \%$ Triton $\mathrm{X}-100$. This was followed by a preincubation in TBS containing 4\% NGS for $30 \mathrm{~min}$. Sections were incubated overnight at $4^{\circ} \mathrm{C}$ in primary antibodies in TBS. Staining was developed as described above. Sections were rinsed in TBS, dehydrated in increasing concentrations of ethanol, clarified, and mounted on coverslips in a xylene-based mounting medium. Sections were also routinely Nissl stained for histological analysis.

\section{Morphometric analysis}

Images were analyzed by using the MCID system (Imaging Research, St. Catharine's, Ontario) to evaluate the area, the total length of the dendritic tree, the number of branches, the diameter of primary dendrites, and the length of dendritic spines. Total length of the dendritic tree was calculated by adding the length of all branches of a single Purkinje cell. In the computation of spine length, no distinction was made between headed spines and filopodia-like processes, although it was clear that MPEP-treated cells bore a lower density of headed spines compared with control sister cultures. Granule cells present in a square of fixed area (1700 $\mathrm{mm}^{2}$; three determinations per slice) were counted in the internal granule layer of comparable sections at the level of preculminate fissure in the anterior cerebellum (lobules 3 and 4). The width of molecular layer was measured in the same region from both anti-calbindin and Nisslstained sections, and comparable results were obtained.

\section{RESULTS}

\section{Endogenous activation of group-I mGlu receptors supports the maturation and survival of cerebellar Purkinje cells in culture}

We used primary cultures of cerebellar neurons prepared from 1 -d-old rats and grown in chemically defined medium with $1 \%$ serum. These cultures contained $\sim 65-70 \%$ granule cells, $10 \%$ Purkinje cells, and 15-20\% glial cells. Purkinje cells were identified by immunostaining with anti-calbindin antibodies (see below). Granule cells were identified by their characteristic morphology (small rounded cell bodies) associated with the absence of GAD-67 or GFAP immunoreactivity. Purkinje cells were viable for at least $21 \mathrm{~d}$. The developmental profile of Purkinje cells in our cultures was identical to that described by Baptista et al. (1994). At 3 DIV, calbindin-stained Purkinje cells showed rounded or fusiform cell bodies and multiple primary aspiny dendrites elongating from the whole cell surface (data not shown). At 6 DIV, most of the primary dendrites were retracted, and Purkinje cells showed a small dendritic tree (Fig. 1, CONTROL). The extension of the dendritic tree progressively increased between 9 and 17 DIV, as shown by the formation and elongation of secondary and tertiary branches (Fig. 1, CONTROL). Spines characterized by a globoid head and a thin neck were clearly visible on dendrites of cultured Purkinje cells after 6 DIV (see Fig. 4A). Under our experimental conditions, the number of Purkinje cells did not change substantially with age in culture, whereas granule cell number decreased by $\sim 50 \%$ between 6 and 13 DIV (Fig. 3A,B).

We have performed immunocytochemical analysis to study the expression of mGlu1a and mGlu5 receptors in culture. mGlu1a receptor immunoreactivity was detected in both Purkinje and granule cells but not in glial cells. At 3 DIV, mGlu1a receptors showed low levels of expression in both neuronal types (data not shown) but were more heavily expressed in Purkinje cells than in granule cells at 6 DIV (Fig. 2A). At 9-13 DIV, Purkinje cells were intensely labeled, and the receptor was apparently present in both the cell soma and dendrites (data not shown). In contrast, mGlu5 receptors were expressed in granule cells and astrocytes but not in Purkinje cells, as demonstrated by double labeling with anti-GFAP (Fig. 2D,E) and anti-calbindin (Fig. 2B,C) antibodies. The expression of mGlu5 receptors did not change between 3 and 9 DIV. No labeling was observed after preadsorbing mGlu1a and mGlu5 antibodies with $100 \mu \mathrm{M}$ of the respective antigenic peptide (data not shown).

To study how endogenous activation of mGlu1 and mGlu5 receptors affects the development of Purkinje cells, we have treated the cultures with CPCCOEt or MPEP, which behave as selective noncompetitive antagonists of mGlu1 and mGlu5 receptors, respectively (Annoura et al., 1996; Gasparini et al., 1999; Litschig et al., 1999). In a first set of experiments, cell cultures were treated daily between 4 and 13 DIV and fixed at 14 DIV. Treatment with either drug dramatically altered the morphology of Purkinje cells. In the majority of treated Purkinje cells, the dendritic tree appeared poor and disorganized with short and thick dendrites, which were always devoid of tertiary branches. No major morphological feature could distinguish MPEP- and CPCCOEt-treated cells. However, MPEP-treated Purkinje cells showed less numerous ( $7.5 \pm 2$ branches; $n=15$ cells $)$ and slightly longer secondary branches than CPCCOEt-treated cells $(15 \pm 2$ branches; $n=12$ cells).

In other experiments, cultures were exposed to CPCCOEt or MPEP from 3 to 6,6 to 9, 9 to 13, or 13 to 17 DIV. In each group, morphological analysis of Purkinje cells and cell counting were 
performed at the end of the treatment. We adopted this strategy to examine how endogenous activation of mGlu1 and mGlu5 receptors regulates the maturation and survival of cerebellar neurons at particular time windows. An early blockade of mGlu1 receptor with CPCCOEt (30 $\mu \mathrm{M}$, from 3 to 6 DIV) substantially reduced the number of Purkinje cells (counted at 6 DIV) without changing the number of granule cells. CPCCOEt had no effect on Purkinje and granule cell survival at any later interval ranging from 6 to 17 DIV. Endogenous blockade of mGlu5 receptors with MPEP $(30 \mu \mathrm{M})$ did not affect the survival of Purkinje cells but reduced the number of granule cells when applied from 3 to 6 or from 6 to 9 DIV (Fig. $3 A, B$ ).

This protocol of antagonist application was also useful for the study of how endogenous activation of mGlu1 or mGlu5 receptors affects the morphology of Purkinje cells (Fig. 1). Purkinje cells exposed to CPCCOEt at early developmental stages (from 3 to 6 or 6 to 9 DIV) appeared smaller and bore short dendrites. This effect was visible with concentrations of 1,10 , and $30 \mu \mathrm{M}$ of CPCCOEt (the effect of $30 \mu \mathrm{M}$ is shown in Fig. 1). In contrast, MPEP had no effect when applied between 3 and 6 DIV but produced profound changes in Purkinje cell morphology at later developmental stages. In cultures exposed to MPEP ( 3 or $30 \mu \mathrm{M})$ from 6 to $9 \mathrm{DIV}$, the majority of Purkinje cells exhibited longer, thinner, and less branched dendrites (Fig. 1). This aberrant developmental pattern was even more evident in cultures exposed to MPEP from 9 to 13 DIV, with Purkinje cell dendrites being longer and often devoid of secondary and tertiary branches (Fig. 1). Morphometric analysis indicated that CPCCOEt applied from 6 to 9 DIV significantly reduced the total length of the dendritic tree and the number of dendritic branches. MPEP affected all of these parameters when applied not only from 6 to 9 DIV but also from 9 to 13 DIV. In addition, the thickness of the primary dendrites of Purkinje cells was significantly reduced in cultures exposed to MPEP at any interval between 6 and 17 DIV (Table 1). The typical morphological features of Purkinje cells treated from 6 to 9 DIV with MPEP were also observed after a $3 \mathrm{~d}$ treatment with SIB-1893 $(30 \mu \mathrm{M})$, which also behaves as a selective noncompetitive mGlu5 receptor antagonist (data not shown). The morphological changes of Purkinje cells observed at 9 DIV after a $3 \mathrm{~d}$ treatment with MPEP were also seen after $24 \mathrm{hr}$ (i.e., between 8 and 9 DIV) but not after 0.5 or $3 \mathrm{hr}$ of drug exposure (data not shown).

Besides producing a substantial effect on the gross morphology of Purkinje cells, a $3 \mathrm{~d}$ treatment with MPEP also influenced the morphogenesis of dendritic spines. Dendrites of Purkinje cells treated with MPEP from 6 to 9 DIV exhibited longer and thinner processes devoid of heads, which markedly differed from the headed mature spines of control cultures. (Fig. 4A-C). CPCCOEt applied from 6 to 9 DIV had no effect on the morphology of dendritic spines (Fig. 4C).

To examine whether Purkinje cells are able to recover from a transient pharmacological blockade of mGlu1 or mGlu5 receptors, we have treated cultures with CPCCOEt or MPEP (both at $30 \mu \mathrm{M}$ ) from 6 to 9 DIV as described previously, but then we have extensively washed the cultures (Fig. 5, legend) and allowed them to grow until 14 DIV. Although Purkinje cells in these cultures showed some morphological abnormalities, their dendrites were more developed than in cultures examined at the end of the $3 \mathrm{~d}$ exposure to CPCCOEt or MPEP, i.e., at 9 DIV, or at the end of
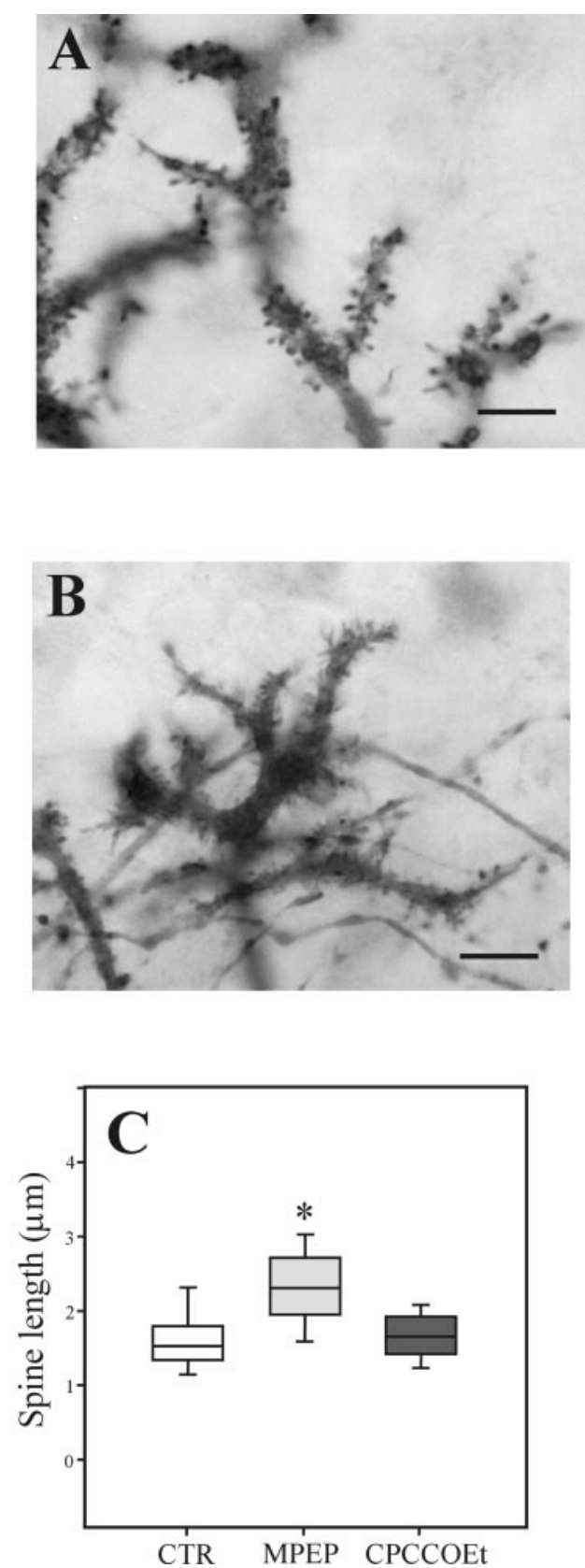

Figure 4. Effects of MPEP or CPCCOEt on the morphology of dendritic spines in cultured Purkinje cells. Drugs were applied to the cultures from 6 to 9 DIV. Note that the dendritic branches of control Purkinje cells at 9 DIV are covered by headed spines $(A)$, whereas dendrites of Purkinje cells treated with MPEP show longer protrusions devoid of heads $(B)$. Kruskal-Wallis one-way ANOVA on ranks revealed a statistically significant difference between groups $(* p<0.05$ by Dunn's method). $C$, Control $(C T R ; n=291), \operatorname{MPEP}(n=220)$, CPCCOEt $(n=287)$; boxes contain $50 \%$ of values; the line dividing the box represents the median $($ control $=1.5 \mu \mathrm{m} ; \mathrm{MPEP}=2.3 \mu \mathrm{m} ;$ CPCCOEt $=1.7 \mu \mathrm{m}) ;$ bottom and top lines represent the 25 th and 75 th percentile, respectively. The number of spines was obtained from 10-15 cells per group from a single experiment performed in triplicate. Identical data were observed in three experiments performed on different culture preparations. Scale bar, $12 \mu \mathrm{m}$.

a continuous exposure to CPCCOEt or MPEP from 6 to 14 DIV (Fig. 5). This indicates that receptor blockade at a critical time window arrests or delays, but does not irreversibly impair, Purkinje cell maturation. 
9 DIV

A

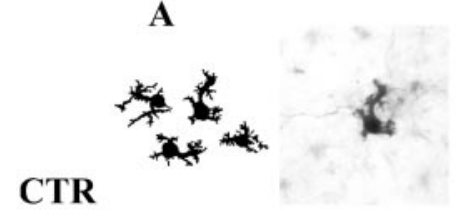

MPEP

C

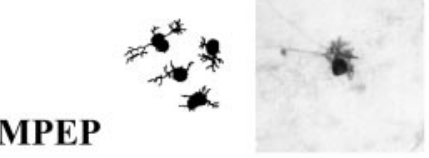

F

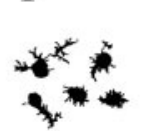

CPCCOEt
14 DIV

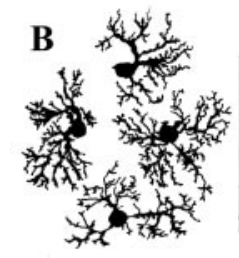

D
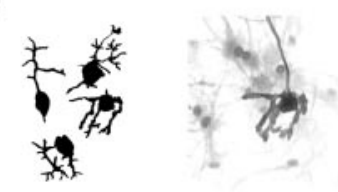

G

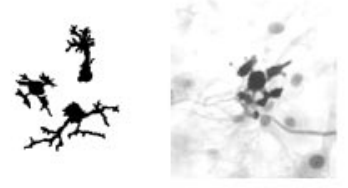

$\mathbf{E}$
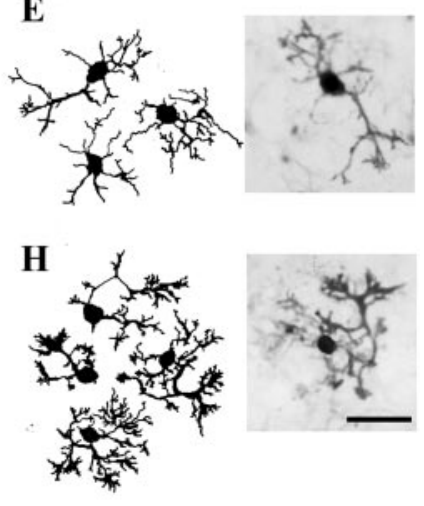

Figure 5. Purkinje cell morphology in cultures treated as follows. $A, C, F, \mathrm{Cul}$ tures treated with culture medium $(A)$, $30 \mu \mathrm{M}$ MPEP (C), or $30 \mu \mathrm{M}$ CPCCOEt (F) from 6 to 9 DIV and examined at 9 DIV; $B, D, G$, Cultures treated with culture medium $(B)$, MPEP $(D)$, or CPCCOEt $(G)$ from 6 to 14 DIV and examined at $14 \mathrm{DIV} ; E, H$, cultures treated with MPEP $(E)$ or CPCCOEt $(H)$ from 6 to 9 DIV, extensively washed (wo), and then examined at 14 DIV. Scale bar, $50 \mu \mathrm{m}$. Note that Purkinje cells partially recover their morphology after $5 \mathrm{~d}$ of drug washout $(E, H)$.

\section{Endogenous activation of mGlu1 and mGlu5 receptors supports the maturation and survival of cerebellar neurons in vivo}

The compounds LY367385 and LY367366, which behave as competitive mGlu1 and mGlu1/5 antagonists, respectively (both at the dose of $20 \mathrm{nmol} / 2 \mu \mathrm{l})$, as well as mGlu1 or mGlu5 antisense oligonucleotides $(12 \mathrm{nmol} / 2 \mu \mathrm{l})$ were injected into the cerebellar region, whereas the noncompetitive mGlu1 antagonist CPCOOEt was injected systemically $(5 \mathrm{mg} / \mathrm{kg}$, s.c.) in neonate rats (see Materials and Methods).

Pups at P9-10 that had been treated with the mGlu1 receptor antagonist LY367385 showed a loss of Purkinje cells, which was remarkable in the vicinity of the injection site. Surviving Purkinje cells showed a shrunken cell body and a poorly developed dendritic tree, which appeared shorter and poorly branched (data not shown). A poorly developed dendritic tree of Purkinje cells was also observed in pups systemically treated with CPCCOEt (Fig. $6 A, B)$ or locally injected with antisense oligonucleotides directed against mGlu1 receptors (Fig. $7 C, F$ ). Antisense treatment was effective in reducing $m$ Glu1a expression in the Purkinje cell layer, as shown by immunohistochemical analysis (Fig. 7, compare $A, B$ with $D, E)$.

Pups injected with mGlu5 antisense oligonucleotides were used for the examination of how mGlu5 receptors affect cerebellar development. To select the animals in which antisense treatment was effective in reducing mGlu5 receptor expression, we performed Western blot analysis of hemicerebella (Fig. 8A). Four of five pups locally injected with antisense showed a clear-cut reduction in the expression of mGlu5 receptors, as compared with pups injected with a scrambled oligonucleotide (Fig. $8 A, S C R$ ). In the other hemicerebella of animals with a proven knockdown of mGlu5 receptors, we observed a reduction in cell number within the granule cell layer (Fig. $8 B, C$ ). Purkinje cells of these animals showed a stellate configuration resulting from the presence of short perisomatic dendrites emerging in all directions (Fig. 7I). There was no reduction in the expression of mGlu1a receptors in pups treated with mGlu5 antisense oligonucleotides (Fig. $7 G, H$ ).

A quantitative assessment of the width of the molecular layer
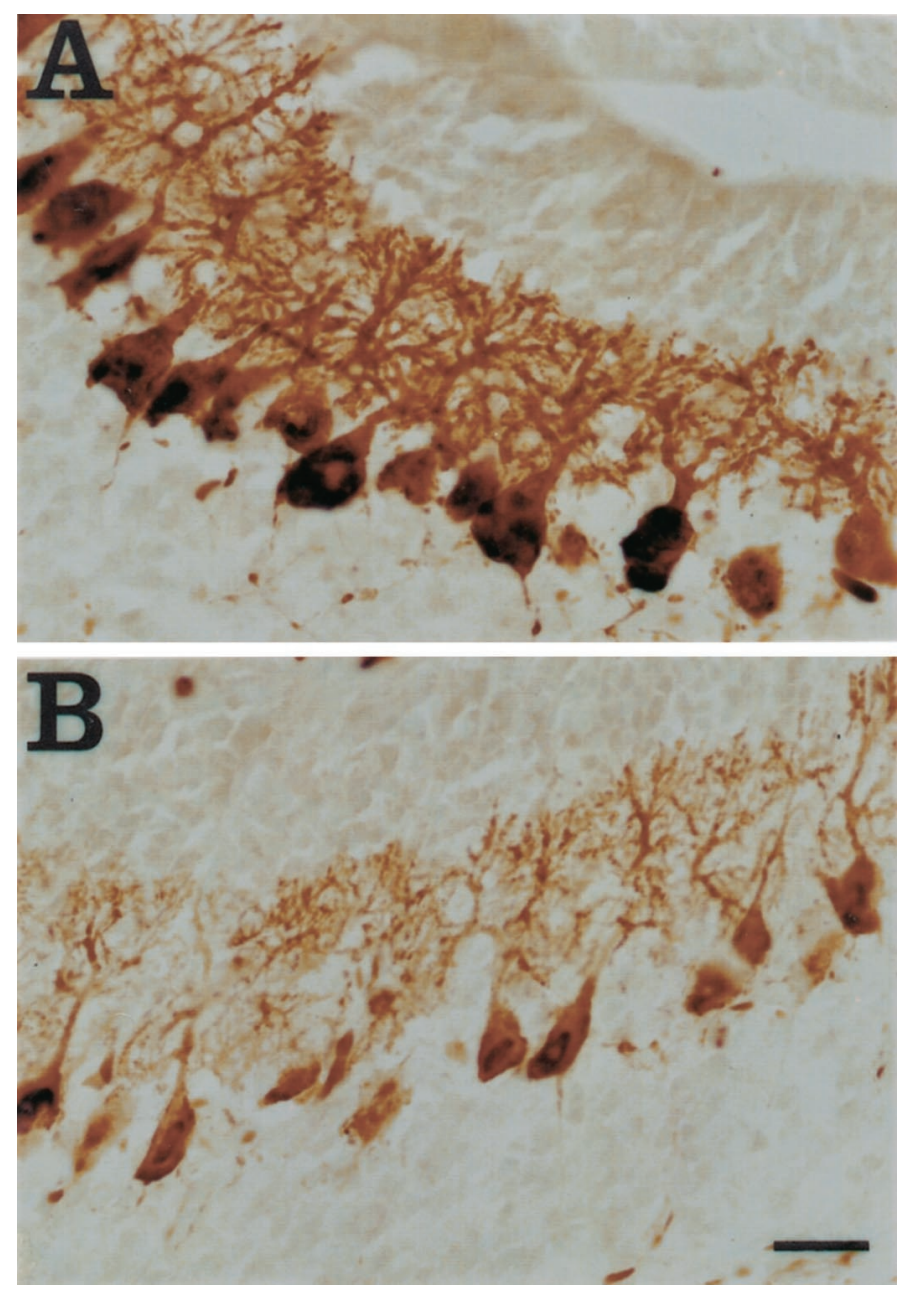

Figure 6. Calbindin immunostaining of Purkinje cells in neonate rats systemically injected with saline $(A)$ or CPCCOEt $(5 \mathrm{mg} / \mathrm{kg}$, s.c.) $(B)$. Note in $B$ a poorly developed dendritic tree of Purkinje cells. Identical data were obtained in four treated pups. Scale bar, $60 \mu \mathrm{m}$. 

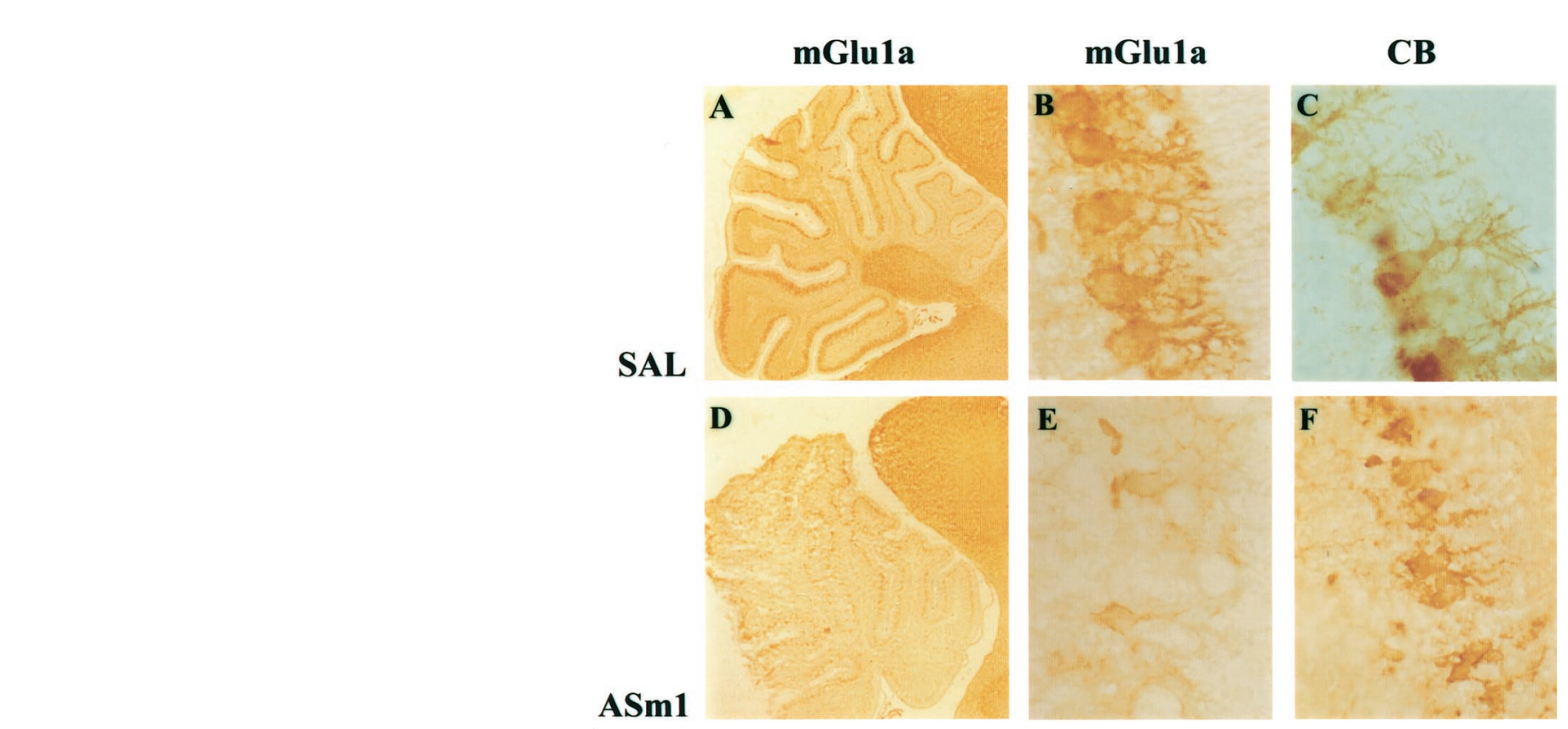

Figure 7. Effects of mGlu1 and mGlu5 antisense treatment on the morphology of Purkinje cells. A substantial reduction of mGlu1a immunostaining is shown in the Purkinje cells of animals treated with mGlu1 antisense oligonucleotides $(D, E)$, as compared with animals injected with saline $(A, B)$ or with animals treated with mGlu5 antisense oligonucleotides $(G, H)$. The effect of the treatment on the morphology of Purkinje cells is shown in $C, F$, and $I$, in which cells are revealed by calbindin immunostaining. Scale bars: $A, D, G, 1 \mathrm{~mm} ; B-I, 20 \mu \mathrm{m}$.
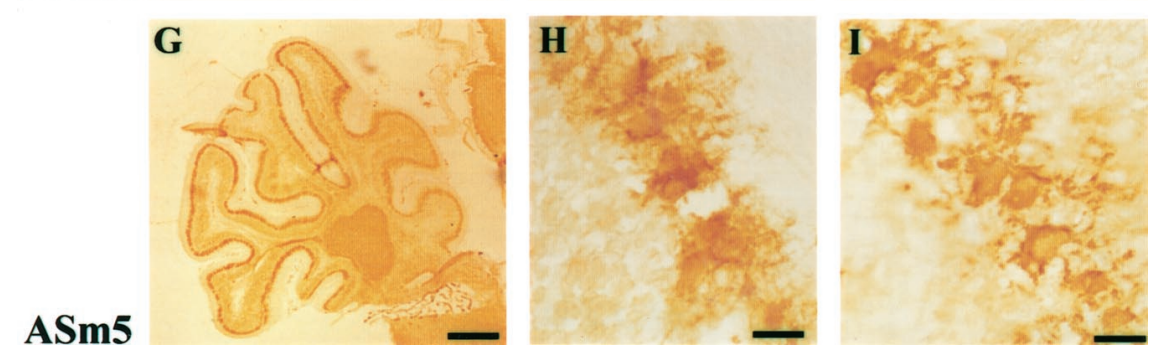

and the number of granule cells after drug or antisense treatment is shown in Figure 9, $A$ and $B$, respectively. Note that (1) treatment with the mGlu1 receptor antagonist LY367385 reduced the width of the molecular layer but not the number of granule cells, (2) treatment with mGlu5 antisense oligonucleotides significantly reduced both the number of granule cells and the width of the molecular layer, and (3) a reduction in the cell number of the granular layer was also observed in pups treated with LY367366, a mixed mGlu1 and mGlu5 receptor antagonist (Fig. 9A,B). Purkinje cells of animals treated with LY376366 were smaller in size, and their dendrites were shorter and not polarized (data not shown).

\section{DISCUSSION}

The major finding of this paper is that endogenous activation of mGlu1 and mGlu5 receptors contributes to cerebellar development and that a selective blockade of these receptors within restricted time windows differentially affects the maturation of Purkinje cells. This discloses a major neurotrophic activity of group-I mGlu receptors during early postnatal development that did not emerge from the use of mGlu1 or mGlu5 knock-out mice (Aiba et al., 1994; Conquet et al., 1994; Lu et al., 1997). Receptor blockade was achieved by using either antisense oligonucleotides or a battery of novel subtype-selective antagonists. CPCCOEt and MPEP (or SIB-1893) behave as potent and noncompetitive antagonists of mGlu1 and mGlu5 receptors, respectively (Annoura et al., 1996; Gasparini et al., 1999; Litschig et al., 1999). LY367385 behaves as a competitive mGlu1 receptor antagonist, whereas LY367366 inhibits both mGlu1 and mGlu5 receptors with equal potency (Clark et al., 1997). The latter two drugs are soluble and were preferred for intracerebral injections.

Mixed cultures of cerebellar Purkinje and granule cells represent a suitable model to examine how endogenous activation of mGlu1 and mGlu5 receptors affects neuronal development. In these cultures, granule cells establish synaptic contacts with Purkinje cells as they do in the intact cerebellum and are known to use glutamate as a neurotransmitter. Hence, noncompetitive antagonists become optimal tools for the examination of how endogenous activation of mGlu1 or mGlu5 receptors affects cell maturation and survival. In culture, pharmacological inhibition of mGlu1 and mGlu5 receptors selectively impaired the survival of Purkinje and granule cells, respectively. Expression of mGlu1a receptors was higher in Purkinje than in granule cells, whereas mGlu5 receptors were expressed in granule cells but not in Purkinje cells. Although information on the expression of other mGlu1 splice variants is lacking, the use of antagonists allows us to conclude that a molecular cascade supporting cell survival is linked to mGlu1 receptors in Purkinje cells and to mGlu5 receptors in granule cells. This is consistent with previous findings showing that the developmental decline in the expression of mGlu5 receptors predisposes cultured granule cells to "low-K $\mathrm{K}^{+}$"induced apoptosis (Copani et al., 1998). Endogenous activation of mGlu1 receptors did not support granule cell survival, although these receptors are functionally coupled with ryanodine-sensitive intracellular $\mathrm{Ca}^{2+}$ stores and L-type voltage-sensitive $\mathrm{Ca}^{2+}$ channels in granule cells (Chavis et al., 1996). Both mGlu1 and mGlu5 receptors are coupled to inositol phospholipid hydrolysis, but they differ in the kinetics of intracellular $\mathrm{Ca}^{2+}$ response. 

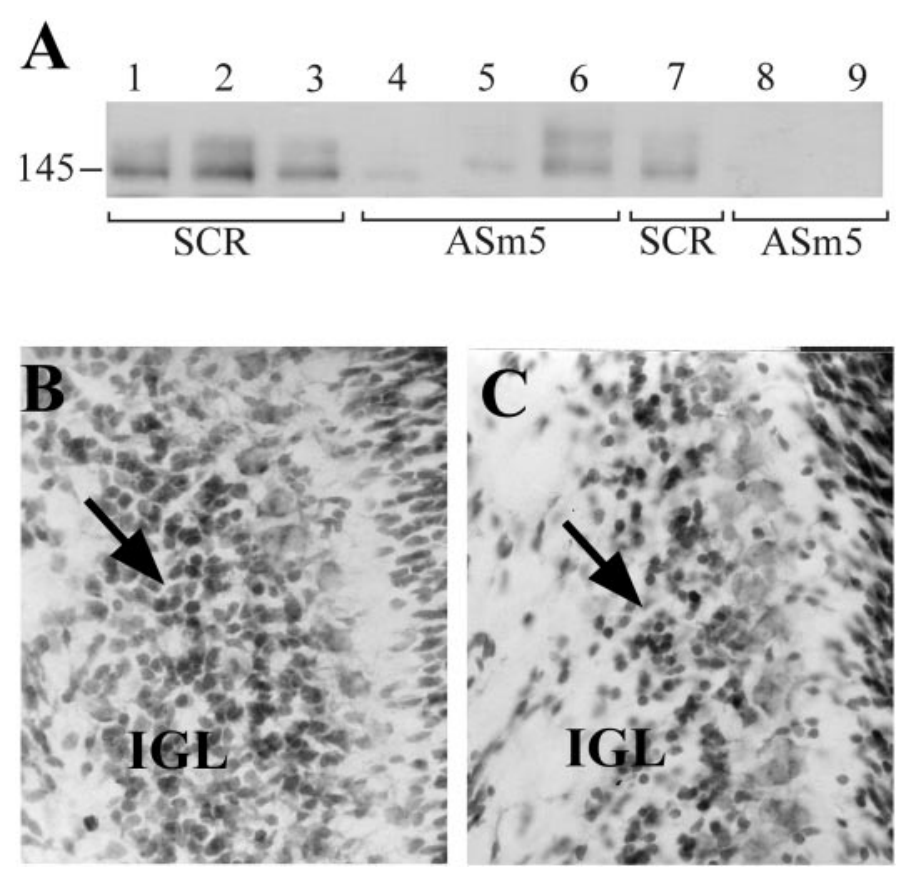

Figure 8. Treatment with mGlu5 antisense oligonucleotides reduces cell density in the internal granular layer $(I G L)$ in neonate rats. $A$, Western blot analysis of mGlu5 receptors in hemicerebella from neonate rats treated with mGlu5 antisense oligonucleotides (ASm5) or with a scrambled oligonucleotide $(S C R)$. Note the reduction in mGlu5 receptor expression in four of the five animals treated with antisense oligonucleotides. An example of the reduction in granule cell density in animals treated with antisense oligonucleotides as compared with animals treated with the scrambled oligonucleotides is shown is $C$ and $B$, respectively (see arrows).

Activation of recombinant mGlu1a receptors generates a single peaked increase in intracellular $\mathrm{Ca}^{2+}$, whereas activation of mGlu5 receptors produces $\mathrm{Ca}^{2+}$ oscillations. The latter property is attributable to a particular threonine residue that is present only in mGlu5 receptors and is phosphorylated by protein kinase C (Kawabata et al., 1996). An attractive hypothesis is that oscillatory increases in intracellular $\mathrm{Ca}^{2+}$ are needed for granule cell viability but are not required for Purkinje cell survival. The use of receptor antagonists in cerebellar cultures revealed that mGlu1 or mGlu5 receptors control cell survival within a restricted time window during early stages of neuronal development. This correlates nicely with evidence that the expression of mGlu5 receptors in granule cells decreases with age (Catania et al., 1994; Copani et al., 1998) and that mGlu1-mediated responses in cultured Purkinje cells peak at 4 DIV and decline thereafter (Yuzaki and Mikoshiba, 1992).

Interestingly, selective blockade of mGlu5 receptors produced substantial morphological changes in Purkinje cells, including changes in the shape of dendritic spines that are consistent with a delay in their maturation (Zif and Smith, 1996; Jontes and Smith, 2000). Because Purkinje cells lack mGlu5 receptors, it is conceivable that MPEP acts primarily on granule cells, which are known to influence Purkinje cell differentiation and survival by releasing glutamate and/or neurotrophins (Baptista et al., 1994; Morrison and Mason, 1998; Hirai and Launey, 2000). Changes in Purkinje cell morphology were particularly evident after 9 DIV and therefore could not be ascribed to the reduction in granule cell number induced by MPEP. However, mGlu5 receptor block-
A

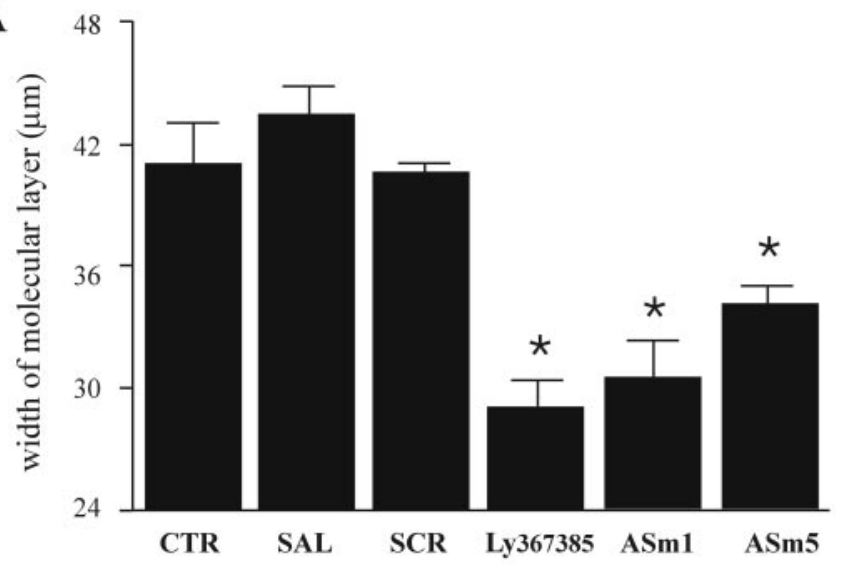

B

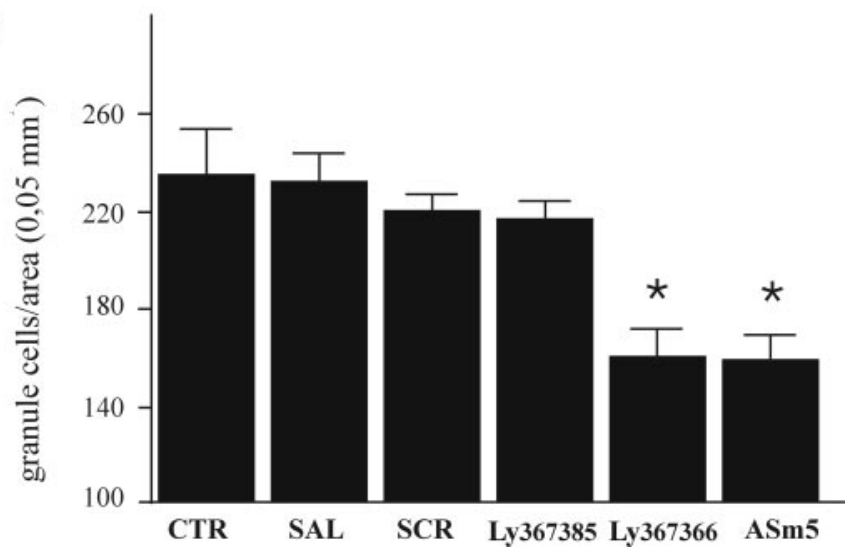

Figure 9. Effects of intracerebral injection of saline, LY367385 (20 nmol), LY367366 (20 nmol), mGlu1, or mGlu5 antisense oligonucleotides $(A S m 1$ or $A S m 5,12 \mathrm{nmol})$ or a scrambled oligonucleotide $(S C R m 5,12 \mathrm{nmol})$ on the width of molecular layer and granule cell number in the cerebellar cortex. The control bar refers to values obtained from noninjected animals. Measurements were taken from the preculminate fissure in the anterior cerebellum. Values are means \pm SEM of three to five animals per group. ${ }^{*} p<0.05$ (one-way ANOVA + Fisher's PLSD) versus control or saline.

ade might have reduced the spontaneous activity of granule cells, thus limiting the major synaptic input to Purkinje cells. Alternatively, inhibition of mGlu5 receptors present in astrocytes might have disrupted a trophic mechanism based on a glial-Purkinje cell interaction. The effects produced by a transient inhibition of mGlu1 or mGlu5 receptors on dendritic growth of Purkinje cells were substantial but not irreversible, as indicated by the partial recovery of the dendritic tree after washing out CPCCOEt or MPEP.

Systemic injections of CPCCOEt and local infusions with LY367385 or mGlu1 antisense oligonucleotides produced morphological abnormalities in the neonate rat cerebellum, which are indicative of an arrest or delay in the maturation of Purkinje cells. These abnormalities (cell shrinkage and dystrophic neurites) are reminiscent of those seen in culture treated with CPCCOEt and strongly suggest that activation of $\mathrm{mGlu} 1$ receptors is required for the early development of Purkinje cells. We did not use MPEP for in vivo studies because high concentrations of MPEP $(>100$ $\mu \mathrm{M})$ may interact with NMDA receptors (Gasparini et al., 1999), and we could not exclude the possibility that such concentrations could be reached in the cerebellum after systemic or local injec- 
tions. For this reason, we used antisense oligonucleotides to examine whether mGlu5 receptors have any role in cerebellar development. Antisense-induced knockdown of mGlu5 receptor was associated with a reduction in granule cell number and alterations in the polarity and arborization of Purkinje cell dendrites, similar to what we observed in cultures treated with MPEP.

In conclusion, we have shown that endogenous activation of mGlu1 and mGlu5 receptors is necessary for a proper development of cerebellar Purkinje cells, with the two receptors operating at different times and on different cells. mGlu1 receptor blockade impaired Purkinje cell development only at early stages of maturation, when dendritic remodeling is presumably independent of innervation by granule cell axons (Armengol and Sotelo, 1991). Interestingly, the expression and subcellular distribution of mGlu1a receptors in Purkinje cells is also independent of synaptic inputs (Takács et al., 1997). Resident astrocytes are a possible source for the glutamate-activating mGlu1 receptors at these early stages of development. Our scenario is clearly different from that reported in mGlu1 knock-out mice, where the only relevant morphological alteration (i.e., the persistence of multiple climbing fiber synapses on Purkinje cells) depends on processes that occur late in development (Kano et al., 1997). mGlu5 receptors might be activated primarily on granule cells or astrocytes and then influence the phenotype of Purkinje cells indirectly, through a synaptic or a paracrine mechanism. These results raise the possibility that changes in the activity of mGlu1 or mGlu5 receptors occurring at critical times of development may contribute to the pathophysiology of cerebellar disorders.

\section{REFERENCES}

Abe T, Sugihara H, Nawa H, Shigemoto R, Mizuno N, Nakanishi S (1992) Molecular characterization of a novel metabotropic glutamate receptor mGluR5 coupled to inositol phosphate/ $\mathrm{Ca}^{2+}$ signal transduction. J Biol Chem 267:13361-13368.

Aiba A, Kano M, Chen C, Stanton ME, Fox GD, Herrup K, Zwingman TA, Tonegawa S (1994) Deficient cerebellar long term depression and impaired motor learning in mGluR1 mutant mice. Cell 79:377-388.

Altman J, Bayer S (1996) An overview of the postnatal development of the rat cerebellum. In: Development of the cerebellar system in relation to its evolution, structure, and function, pp 324-333. Boca Raton, FL: CRC.

Annoura H, Fukunaga A, Uesugi M, Tatuoka T, Horikawa Y (1996) A novel class of antagonists for metabotropic glutamate receptors, 7-(hydroxyimino)cyclopropa[b]chromen-1a-carbozylates. Bioorg Med Chem Lett 5:223-228.

Aramori I, Nakanishi S (1992) Signal transduction and pharmacological characteristics of a metabotropic glutamate receptor, mGluR1, in transfected CHO cells. Neuron 8:757-765.

Armengol J-H, Sotelo C (1991) Early dendritic development of Purkinje cells in the rat cerebellum. A light and electron microscopic study using axonal tracing in "in vitro" slices. Dev Brain Res 64:95-114.

Aronica E, Condorelli DF, Nicoletti F, Dell'Albani P, Amico C, Balázs R (1993) Metabotropic glutamate receptors in cultured cerebellar granule cells: developmental profile. J Neurochem 60:559-565.

Balázs R, Jorgenson OS, Hack N (1988) N-methyl-D-aspartate promotes the survival of cerebellar granule cells in culture. Neuroscience 27:437-451.

Baptista CA, Hatten ME, Blazeski R, Mason CA (1994) Cell-cell interactions influence survival and differentiation of purified Purkinje cells in vitro. Neuron 12:243-260.

Burgoyne RD, Graham ME, Cambray-Deakin M (1993) Neurotrophic effects of NMDA receptor activation on developing cerebellar granule cells. J Neurocytol 22:689-695.

Casabona G, Knöpfel T, Kuhn R, Gasparini F, Baumann P, Sortino MA, Copani A, Nicoletti F (1997) Expression and coupling to polyphosphoinositide hydrolysis of group-I metabotropic glutamate receptors in early postnatal and adult rat brain. Eur J Neurosci 9:12-17.
Catania MV, Landwehrmeyer GB, Testa CM, Standaert DM, Penney Jr HB, Young AB (1994) Metabotropic glutamate receptors are differentially regulated during development. Neuroscience 61:481-495

Chavis P, Fagni L, Lansman JB, Bockaert J (1996) Functional coupling between ryanodine receptors and L-type calcium channels in neurons. Nature 382:719-722.

Clark BP, Baker SR, Goldsworthy J, Harris JR, Kingston AE (1997) 2.methyl-4-carboxyphenylglycine (LY367385) selectively antagonises metabotropic glutamate receptors. Bioorg Med Chem Lett 7:2777-2780

Conquet F, Bashir ZI, Davies CH, Daniel H, Ferraguti F, Bordi F, Franz-Bacon K, Reggiani A, Matarese V, Condé F, Collingridge GL, Crépel F (1994) Motor deficit and impairment of synaptic plasticity in mice lacking mGluR1. Nature 372:237-243.

Copani A, Casabona G, Bruno V, Caruso A, Condorelli DF, Messina A, Di Giorgi Gerevini V, Pin J-P, Kuhn R, Knopfel T, Nicoletti F (1998) The metabotropic glutamate receptor mGlu5 controls the onset of developmental apoptosis in cultured cerebellar neurons. Eur J Neurosci 10:2173-2184.

Dudek SM, Bear M (1989) A biochemical correlate of the critical period for synaptic modification in the visual cortex. Science 246:673-675.

Furuya S, Makino A, Hirabayashi Y (1998) An improved method for culturing cerebellar Purkinje cells with differentiated dendrites under a mixed monolayer setting. Brain Res Brain Res Protoc 3:192-198.

Gasparini F, Lingenhöhl K, Stoehr N, Flor PJ, Heinrich M, Vranesic I, Biollaz M, Allgeier H, Heckendorn R, Urwyler S, Varney MA, Johnson EC, Hess SD, Rao SP, Sacaan AI, Santory EM, Velicelebi G, Kuhn R (1999) 2-Methyl-6-(phenylethynyl)-pyridine (MPEP), a potent, selective and systemically active mGlu5 receptor antagonist. Neuropharmacology 38:1493-1503.

Görcs TJ, Penke B, Böti Z, Katarova Z, Hámori J (1993) Immunohistochemical visualization of a metabotropic glutamate receptor. NeuroReport 4:283-286.

Hirai H, Launey T (2000) The regulatory connection between the activity of granule cell NMDA receptors and dendritic differentiation of cerebellar Purkinje cells. J Neurosci 20:5217-5224.

Houamed KM, Kuijper J, Gilbert TL, Haldeman BA, O'Hara PJ, Mulvihill ER, Almers W, Hagan FS (1991) Cloning, expression and gene structure of a G-protein-coupled glutamate receptor from rat brain. Science 252:1318-1321.

Jontes JD, Smith SJ (2000) Filopodia, spines, and the generation of synaptic diversity. Neuron 27:11-14.

Kano M, Hashimoto K, Kurihara H, Watanabe M, Inoue Y, Aiba A, Tonegawa S (1997) Persistent multiple climbing fiber innervation of cerebellar Purkinje cells in mice lacking mGluR1. Neuron 18:71-79.

Kawabata S, Tsutsumi R, Kohara A, Yamaguchi T, Nakanishi S, Okada M (1996) Control of calcium oscillations by phosphorylation of metabotropic glutamate receptors. Nature 383:89-92.

Litschig S, Gasparini F, Rueegg D, Stoehr N, Flor PJ, Vranesic I, Prezeau L, Pin J-P, Thomsen C, Kuhn R (1999) CPCCOEt, a noncompetitive metabotropic glutamate receptor 1 antagonist, inhibits receptor signaling without affecting glutamate binding. Mol Pharmacol 55:453-461.

Lu Y-M, Jia Z, Janus C, Henderson JH, Gerali R, Wojtowicz JM, Roder JC (1997) Mice lacking metabotropic glutamate receptor 5 show impaired learning and reduced CA1 long-term potentiation (LTP) but normal CA3 LTP. J Neurosci 17:5196-5205.

Marini AM, Rabin SJ, Lipsky RH, Mocchetti I (1998) Activitydependent release of brain-derived neurotrophic factor underlies the neuroprotective effect of $N$-methyl-D-aspartate. J Biol Chem 273:2934-2939.

Minakami R, Iida K-I, Hirakawa N, Sugiyama H (1995) The expression of two splice variants of metabotropic glutamate receptor subtype 5 in the rat brain and neuronal cells during development. J Neurochem 65:1536-1542.

Moran J, Patel AJ (1989) Stimulation of the $N$-methyl-D-aspartate receptor promotes the biochemical differentiation of cerebellar granule neurons and not astrocytes. Brain Res 486:15-25.

Morrison ME, Mason CA (1998) Granule neuron regulation of Purkinje cell development: striking a balance between neurotrophin and glutamate signaling. J Neurosci 18:3563-3573.

Mount HTJ, Dreyfus CF, Black IB (1993) Purkinje cell survival is differentially regulated by metabotropic and ionotropic excitatory amino acid receptors. J Neurosci 13:3173-3179.

Nakanishi S (1982) Molecular diversity of glutamate receptors and implications for brain function. Science 258:597-603.

Nicoletti F, Wroblewski JT, Novelli A, Alho H, Guidotti A, Costa E (1986) The activation of inositol phospholipid hydrolysis as a signal transducing system for excitatory amino acids in primary cultures of cerebellar granule cells. J Neurosci 6:1905-1911. 
Pin J-P, Duvoisin R (1995) The metabotropic glutamate receptors: structure and functions. Neuropharmacology 34:1-26.

Rabacchi S, Bailly Y, Delhaye-Bouchaud N, Mariani J (1992) Involvement of the $N$-methyl-D-aspartate (NMDA) receptor in synapse elimination during cerebellar development. Science 256:1823-1825.

Romano C, Van den Pol A, O’Malley KL (1996) Enhanced early developmental expression of the metabotropic glutamate receptor mGluR5 in rat brain: protein, mRNA splice variants, and regional distribution. J Comp Neurol 367:403-412.

Schoepp DD, Johnson BG (1989) Inhibition of excitatory amino acidstimulated phosphoinositide hydrolysis in the neonatal rat hippocampus by 2-amino-3-phosphonoproprionate. J Neurochem 530:1865-1870.
Takács J, Gombos G, Görcs T, Becker T, de Barry J, Hámori J (1997) Distribution of metabotropic glutamate receptor type 1a in Purkinje cell dendritic spines is independent of the presence of presynaptic parallel fibers. J Neurosci Res 50:433-442.

Yuzaki M, Mikoshiba K (1992) Pharmacological and immunocytochemical characterization of metabotropic glutamate receptors in cultured Purkinje cells. J Neurosci 12:4253-4263.

Yuzaki M, Forrest D, Verselis LM, Sun SC, Curran T, Connor JA (1996) Functional NMDA receptors are transiently active and support the survival of Purkinje cells in culture. J Neurosci 16:4651-4661.

Zif NM, Smith SJ (1996) Evidence for a role of dendritic filopodia in synaptogenesis and spine formation. Neuron 17:91-102. 